НАУКОВИЙ ВІСНИК

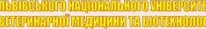

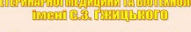

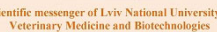

mingen

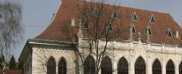

(2)

Том 22 № 94

\section{Науковий вісник Яьвівського національного університету} ветеринарної медицини та біотехнодогій імені С.3. Гжицького.

Серія: Харчові технології

\author{
Scientific Messenger of Lviv National University \\ of Veterinary Medicine and Biotechnologies.
}

Series: Food Technologies

UDC 331.45: 004.9

\title{
The example of evaluating the effectiveness of the management system of labor protection of the enterprise with the method of multicriteria selection of alternatives based on a fuzzy advantage ratio
}

\author{
T. V. Olyanyshen ${ }^{1}$, V. M. Storozhuk ${ }^{1}$, R. A. Yatsiuk ${ }^{2}$, B. P. Chaikovskyi ${ }^{3}$, I. H. Yaroshovych', \\ Yu. V. Ratushniak ${ }^{4}$ A. V. Melnikov ${ }^{4}$ \\ ${ }^{1}$ Ukrainian National Forestry University, Lviv, Ukraine \\ ${ }^{2}$ National University "Lviv Polytechnik”, Lviv, Ukraine \\ ${ }^{3}$ Stepan Gzhytskyi National University of Veterinary Medicine and Biotechnologies Lviv, Ukraine \\ ${ }^{4}$ IT Step University, Lviv, Ukraine
}

\section{Article info}

Received 07.09.2020

Received in revised form 07.10 .2020

Accepted 08.10.2020

Ukrainian National Forestry University, Gen. Chuprynka St., 103, Lviv, 79057, Ukraine. Tel : +38-032-238-45-02

E-mail:vik100r@meta.ua

National University "Lviv Polytechnik", St. Bandery Str. 12 Lviv, 79000, Ukraine. Tel.: +38-032-258-25-09 E-mail:ros.yatsiuk@gmail.com

Stepan Gzhytskyi National University of Veterinary Medicine and Biotechnologies Lviv,

Pekarska Str., 50, Lviv,

79010, Ukraine.

IT Step University, Zamarstynivska Str., 83A, Lviv, 79011, Ukraine. Tel : +38-032-240-38-5I E-mail: e_research@ukr.net
Olyanyshen, T. V., Storozhuk, V. M., Yatsiuk, R. A., Chaikovskyi, B. P., Yaroshovych, I.H., Ratushniak, Yu. V., \& Melnikov, A. V. (2020). The example of evaluating the effectiveness of the management system of labor protection of the enterprise with the method of multicriteria selection of alternatives based on a fuzzy advantage ratio. Scientific Messenger of Lviv National University of Veterinary Medicine and Biotechnologies. Series: Food Technologies, 22(94), 44-49. doi: $10.32718 /$ nvlvet-f9409

The management system of labor protection (MSLP) is an effective tool, which allows the business entity to provide the proper level of labor protection on the enterprises, that corresponds to the requirements of safe and healthy conditions of work for employees. The approaches of construction and functioning of MSLP are improving based on international experience. In 2018 the Cabinet of Ministers of Ukraine has approved "The concept of reforming the management system of labor protection in Ukraine”, which basing on a risk-oriented approach determines the principles, directions and tasks of building a system of labor safety and health in Ukraine and aims to create the national system of production risks prevention and to ensure safe and healthy working conditions for employees. This article deals with the use of the method of multicriteria choice of alternatives based on fuzzy advantage ratio in the process of evaluating the effectiveness of the labor protection management system of enterprises, that allows more objectively identify threats to efficiency of MSLP of the specific business entity. There are some examples of usages of this method to solve issues related to ensuring the economic security of economic entities. Based on those scientific works authors tried to evaluate the effectiveness of functioning of MSLP. The solution of this problem was carried out on the example of a specific chemical enterprise. The department of Life Safety of the National Forestry University of Ukraine has carried out significant work to identify threats to efficiency of MSLP, related to the activities of the labor protection service, which in this article are considered as a set of acceptable alternatives and could be the threat for MSLP efficiency. Also, there were identified some criteria for selecting among the identified threats (acceptable alternatives): the threat occurs infrequently and irregularly; the appearance of threats from time to time; threat occurs frequently and regularly (recurrence of the threat) over a period of time. In the course of the work, the most significant threats were found. That is, the problem of rational choice of alternatives from a certain set $X$ was solved, for which some fuzzy advantage ratio is given $g_{1}, g_{2}, g_{3}$ with the function $\mu_{g j}: X \times X \rightarrow(0,1)$. To solve the problem of multicriteria selection described above, was select an effective method of convolution of the vector criterion into a scalar. The results show that the most significant threats to efficiency of MSLP of the enterprise that was analyzed is an excess of the frequency of injuries at the enterprise over the frequency in the industry and a gross violation of occupational safety rules, accidents. The results obtained indicate that an accident has occurred or may occur at the assessed enterprise. The use of the method of multi-criteria selection of alternatives on the basis of a fuzzy ratio of advantages in the process of evaluating the effectiveness of the management system of labor protection of the enterprise allows more objectively identify shortcomings of MSLP, that potentially lead to undesirable consequences and, accordingly, take the necessary measures in time to normalize the situation.

Key words: The management system of labor protection, threats to the efficiency of the system functioning, the method of multicriteria selection of alternatives based on a fuzzy advantage ratio. 


\title{
Приклад оцінювання ефективності системи управління охороною праці підприсмства із застосуванням методу багатокритеріального вибору альтернатив на основі нечіткого відношення переваги
}

\author{
Т. В. Олянишен ${ }^{1}$, В. М. Сторожук ${ }^{1}$ Р. А. Яцюк ${ }^{2}$, Б. П. Чайковський구 І. Г. Ярошович ${ }^{3}$, \\ Ю. В. Ратушняк ${ }^{4}$ О. В. Мельников ${ }^{4}$
}

${ }^{1}$ Національний лісотехнічний університет Украйни, м. Львів, Украӥна

${ }^{2}$ Національний університет “Львівська політехніка", м. Львів, Украйна

3Львівський національний університет ветеринарної медицини та біотехнологій імені С. 3. Гжищького, м. Львів, Украӥна

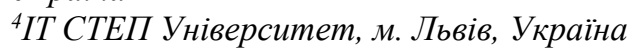

\begin{abstract}
Система управління охороною праиі (СУОП) є ефективним інструментом, який дозволяє суб 'єкту господарювання забезпечити належний рівень охорони праці на підприємстві, що відповідає необхідним вимогам щодо забезпечення безпечних $і$ здорових умов прачі працівників. Підходи до побудови та функціонування СУОП постійно удосконалюються із урахуванням міжнародного досвіду. У 2018 р. розпорядженням Кабінету Міністрів України схвалена «Концепція реформування системи управління охороною праці в Україні», яка на основі ризикоорієнтованого підходу визначає принципи, напрями і завдання побудови системи організаціі безпеки та гігієни праиі в Україні з метою створення національної системи запобігання виробничим ризикам для забезпечення ефективної реалізачії права прачівників на безпечні та здорові умови прачі. У даний роботі розглядається застосування методу багатокритеріального вибору альтернатив на основі нечіткого відночення переваги в процесі оцінювання ефективності системи управління охороною прачі підприємства, що дозволить більщ об'єктивно виявити загрози ефективності СУОП конкретного суб' 'єкта господарювання. Відомі приклади застосування иього методу для розв 'язання задач пов'язаних із забезпеченням економічної безпеки суб'єктів господарювання. Грунтуючись на иих роботах автори спробували оцінити ефективність функиіонування СУОП. Розв'язання поставленої задачі було здійснено на прикладі конкретного підприємства хімічної промисловості. Кафедрою безпеки життєдіяльності Національного лісотехнічного університету України була проведена значна робота з виокремлення загроз ефективності СУОП, пов'язаних із діяльністю служби охорони праці, які в даній роботі розглядаються як множина допустимих альтернатив, які з точки зору їх появи становлять загрозу ефективності СУОП. Також були визначені критерії, за якими здійснюється вибір серед визначених загроз (допустимих альтернатив): загроза трапляється нечасто і нерегулярно; появ загрози час від часу; загроза трапляється часто і регулярно (повторюваність появи загрози) упродовж певного періоду часу. У процесі виконання роботи були знайдені найбільш вагомі загрози відносно визначених критерї̈в. Тобто була розв'язана задача рачіонального вибору альтернатив з певної множини $X$, для якої задано деяке нечітке відношення переваги $g_{1}, g_{2}, g_{3}$ з функиіями належності $\mu_{g j}: X \times X \rightarrow(0,1)$. Для вирішення сформульованої задачі багатокритеріального вибору обрався ефективний спосіб згортки векторного критерію в скалярний. Отримані результати демонструють, що найбільш вагомими загрозами ефективності СУОП аналізованого підприємства є перевищення частоти травматизму на підприємстві над частотою по галузі та грубе порушення правил безпеки праиі, допущення аварій. Отримані результати свідчать про те що на оцінюваному підприємстві відбувся чи може відбутися нещасний випадок. Застосування методу багатокритеріального вибору альтернатив на основі нечіткого відношення переваги в процесі оцінювання ефективності системи управління охороною праиі підприємства, розглянуте в роботі, дозволяє, на відміну від низки інших методів, більш об'єктивно виокремити недоліки в СУОП, які потенџійно можуть призвести до небажаних наслідків $і$, відповідно, вчасно вжити необхідні заходи для нормалізаџї ситуаиї̈.
\end{abstract}

Ключові слова: Система управління охороною праці, загрози ефективності функціонування системи, метод багатокритеріального вибору альтернатив на основі нечіткого відночення переваги

\section{Вступ}

Система управління охороною праці (СУОП) є ефективним інструментом, який дозволяє суб'єкту господарювання забезпечити належний рівень охорони праці на підприємстві, що відповідає необхідним вимогам щодо забезпечення безпечних і здорових умов праці працівників.

Питання впровадження СУОП впродовж багатьох років залишаються актуальними для суб'єктів виробничої та невиробничої сфер діяльності та мають відповідне нормативне підгрунтя. Так, ст. 13 Закону України "Про охорону праці" (Pro okhoronu pratsi, 1992) зобов'язує роботодавця забезпечити функціонування системи управління охороною праці. 3 метою сприяння створенню ефективної СУОП у 2008 р. Держгірпромнаглядом були затверджені Рекомендації щодо побудови, впровадження та удосконалення системи управління охороною праці (Pro Rekomendatsii shchodo pobudovy..., 2008). Розроблялись і галузеві нормативні документи щодо СУОП, наприклад, “По- ложення про Систему управління охороною праці на підприємствах електроенергетики" (Pro zatverdzhennia Polozhennia pro Systemu upravlinnia..., 2015).

Підходи до побудови та функціонування СУОП постійно удосконалюються із урахуванням міжнародного досвіду. У 2018 р. розпорядженням Кабінету Міністрів України схвалена "Концепція реформування системи управління охороною праці в Україні” (Pro skhvalennia Kontseptsii..., 2018), яка на основі ризикоорієнтованого підходу визначає принципи, напрями i завдання побудови системи організації безпеки та гігієни праці в Україні з метою створення національної системи запобігання виробничим ризикам для забезпечення ефективної реалізації права працівників на безпечні та здорові умови праці.

Аналіз останніх публікацій за проблематикою та визначення невирімених раніше частин загальної проблеми. Питання розроблення ефективної СУОП $є$ актуальним як для вітчизняних підприємств, так і для закордонних, про що свідчать міжнародні нормативні документи, що приймались в різний час, наприклад: 
рекомендації ILO-OSH 2001 (ILO-OSH 2001), стандарт ISO 45001:2018 (відповідно, в Україні 3 01.01.2021 вводиться ДСТУ ISO 45001:2019) “Системи управління охороною здоров'я та безпекою праці. Вимоги та настанови щодо застосування" (DSTU ISO 45001:2019).

Проблемам СУОП, іiі формуванню, оптимізації та оцінюванню ефективності присвячена низка публікацій, як навчально-методичних, так і наукових, зокремa, (Hohitashvili, 2002; Hohitashvili et al., 2007; Storozhuk, 2015; Hohitashvili et al., 2016; Storozhuk et al., 2016; Storozhuk et al., 2019).

Незважаючи на це, тема оцінювання ефективності СУОП не вичерпана, оскільки тут підходи можуть бути різноманітними, що зумовлено особливостями суб'єкта господарювання - виробнича чи невиробнича сфера діяльності, наявність об'єктів, устаткування, робіт підвищеної небезпеки, особливості виробничого процесу загалом і технологічних процесів зокрема, вертикальних і горизонтальних зв’язків у підрозділах і виробництвах компанії, кількість та підготовленість персоналу тощо.

\section{Результати та їх обговорення}

Пропонований у роботі підхід до оцінювання ефективності системи управління охороною праці підприємства базується на застосуванні методу багатокритеріального вибору альтернатив на основі нечіткого відношення переваги, що описаний у роботах (Zaichenko, 1991; 2006). Відомі приклади застосування цього методу для розв'язання задач пов'язаних із забезпеченням економічної безпеки суб'єктів господарювання (Zhyvko, 2013; Melnikov \& Karaim, 2013; Karaim et al., 2016). Грунтуючись на цих роботах автори спробували оцінити ефективність функціонування СУОП. Нижче наведена розв'язання поставленої проблеми на прикладі конкретного підприємства хімічної промисловості.

Свого часу на кафедрі безпеки життєдіяльності Національного лісотехнічного університету України була проведена значна робота з виокремлення загроз ефективності СУОП, пов'язаних із діяльністю служби охорони праці (Storozhuk et al., 2006), перелік яких бачимо в табл. 1. Фактично задана множина допустимих альтернатив, які з точки зору їх появи становлять загрозу ефективності СУОП $-x_{i} i y_{i}, i=1, n$.

\section{Таблиця 1}

Загрози, пов’язані із діяльністю служби охорони праці, що можуть негативно впливати на ефективність СУОП

\begin{tabular}{lc}
\hline \multicolumn{1}{c}{ Загроза } & $x_{i}$ \\
\hline Низький рівень наочної агітації з безпеки праці & $x_{25}$ \\
Невиконання діючих вимог щодо ведення документації з охорони праці & $x_{26}$ \\
Невиконання запланованих заходів у визначені терміни & $x_{27}$ \\
Невиконання приписів з охорони праці у визначені терміни & $x_{28}$ \\
Порушення періодичності контролю за станом охорони праці в структурних підрозділах & $x_{29}$ \\
Перевищення частоти травматизму на підприємстві над частотою по галузі & $x_{30}$ \\
Перевищення важкості травматизму на підприємстві над важкістю по галузі & $x_{31}$ \\
Невиконання заходів, передбачених в актах з розслідування нещасних випадків у визначені терміни & $x_{32}$ \\
Непідготовленість персоналу з охорони праці & $x_{33}$ \\
Порушення періодичності проведення інструктажів, атестації та переатестації з безпеки праці & $x_{34}$ \\
Грубе порушення правил безпеки праці, допущення аварій & $x_{35}$ \\
Невикористання робітниками засобів індивідуальних захисту та спецодягу & $x_{36}$ \\
Рівень забезпеченості побутовими приміщеннями & $x_{37}$ \\
Надпланове виконання заходів щодо покращення умов праці & $x_{38}$ \\
Впровадження пропозицій щодо покращення умов праці & $x_{39}$ \\
\hline
\end{tabular}

Наступним кроком стало визначення критеріїв, за якими здійснюється вибір серед визначених загроз (допустимих альтернатив) $g_{j}, j=1, m$ (табл. 2).

\section{Таблиця 2}

Критерії, за якими здійснюється вибір серед визначених загроз, що можуть негативно впливати на ефективність СУОП

\begin{tabular}{cl}
\hline$g_{j}$ & \multicolumn{1}{c}{ Зміст критерію } \\
\hline$g_{1}$ & $\begin{array}{l}\text { загроза трапляється нечасто і нерегулярно } \\
g_{2}\end{array}$ \\
$g_{3}$ & $\begin{array}{l}\text { поява загрози час від часу } \\
\text { рювана трапляється часто і регулярно (повто- } \\
\text { періоду часу }\end{array}$ \\
\hline
\end{tabular}

У процесі виконання роботи визначені найбільш вагомі загрози відносно визначених критеріїв. Тобто стояло завдання раціонального вибору альтернатив 3 певної множини $X$, для якої задано деяке нечітке відношення переваги $g_{1}, g_{2}, g_{3}$ з функціями належності $\mu_{g \mathrm{j}}: X \times X \rightarrow(0,1)$.

Для визначення $\omega_{i}-$ ваги $i$-го критерію на основі експертних опитувань 3 використанням шкали відносної важливості об'єктів (Saaty, 1993; Melnikov, 2018) було сформовано матрицю парних порівнянь (табл. 3).

Зроблено це наступним чином: для двох альтернатив, що порівнювалися між собою (табл. 3), залежно від їх важливості та міри впливу на вибір серед визначених загроз отримані відповідні значення відповідного елемента матриці парних порівнянь у позиції $\left(g_{j}, g_{m}\right)$. 


\section{Таблиця 3}

Матриця парних порівнянь критеріїв, за якими здійснюється вибір серед визначених зовнішніх загроз, що можуть негативно впливати на ефективність СУОП

\begin{tabular}{llcc}
\hline$g_{j}$ & $g_{1}$ & $g_{2}$ & $g_{3}$ \\
\hline$g_{1}$ & 1 & $1 / 7$ & $1 / 9$ \\
$g_{2}$ & 7 & 1 & $1 / 3$ \\
$g_{3}$ & 9 & 3 & 1 \\
\hline
\end{tabular}

Згідно визначених умов (Saaty 1993; Melnikov, 2018) діагональні елементи матриці дорівнюють одиниці. Нижня частина матриці заповнюється оберненими значеннями. При незначних відмінностях між вагами критеріїв можна також використовувати парні числа 2, 4, 6 та їх обернені значення (Semeniuk et al., 2012).

Здійснені далі за допомогою комп’ютерної програми розрахунки дозволилк. визначити суми елементів стовпців матриці парних порівнянь

$$
E_{n}=(0,056 ; 0,289 ; 0,655) .
$$

За результатами проведених розрахунків було визначено, що індекс узгодженості матриці парних порівнянь (табл. 3) в межах норми $(\leq 0,1)$, тобто маємо задовільні результати порівнянь. Отримані ваги критеріїв, за якими здійснюється вибір серед визначених загроз для:

- загроза трапляється нечасто i нерегулярно: $\omega_{1}=0,056$

- появ загрози час від часу: $\omega_{2}=0,289$;

- загроза трапляється часто і регулярно (повторюваність появи загрози) упродовж певного періоду часу: $\omega_{3}=0,655, \sum_{j=1}^{n} \omega_{j}=1$.

Для вирішення сформульованої задачі багатокритеріального вибору обирався ефективний спосіб згор- тки векторного критерію в скалярний (Zaichenko, 1991).

Перший спосіб згортки: $Q_{1}=\bigcap_{j=1}^{m} g_{j}-$ береться перетин заданих співвідношень переваги.

Другий спосіб - згортка вихідних відношень $g_{j}$ у вигляді суми:

$$
Q_{2}=\sum_{j=1}^{m} \omega_{j} g_{j}
$$

Далі знаходилася найкраща альтернатива за обома згортками.

За кожним 3 критеріїв $g_{j}$ парно порівнювалися загрози, що можуть негативно впливати на ефективність СУОП. Результати оцінювались наступним чином:

$$
\mu_{g_{j}}\left(x_{i}, x_{j}\right)=\left\{\begin{array}{c}
1, \text { якщо } x_{i} \succ x_{j} \text { або } x_{i} \approx x_{j} \\
0, \text { якщзо } x_{i} \prec x_{j}
\end{array}\right.
$$

де $x_{i}, x_{j}$ - загрози, пов'язані із діяльністю служби охорони праці, що можуть негативно впливати на ефективність СУОП.

Узагальненні думки експертів для аналізованого підприємства, щодо переваги тієї чи іншої загрози (табл. 1) над іншою з врахуванням критеріїв, за якими здійснюється вибір бачимо нижче:

- загроза трапляється нечасто і нерегулярно, $g_{1}$ :

$$
\begin{aligned}
& \text { - } \quad x_{25} \prec x_{26}, x_{25} \prec x_{27}, x_{25} \prec x_{28}, x_{25} \prec x_{29}, x_{25} \prec x_{30}, x_{25} \prec x_{31}, x_{25} \prec x_{32}, x_{25} \prec x_{33}, x_{25} \prec x_{34} \text {, } \\
& x_{25} \prec x_{35}, x_{25} \prec x_{36}, x_{25} \prec x_{37}, x_{25} \prec x_{38}, x_{25} \prec x_{39} \text {, } \\
& x_{26} \approx x_{27}, x_{26} \approx x_{28}, x_{26} \approx x_{29}, x_{26} \prec x_{30}, x_{26} \prec x_{31}, x_{26} \approx x_{32}, x_{26} \prec x_{33}, x_{26} \approx x_{34}, x_{26} \prec x_{35}, \\
& x_{26} \approx x_{36}, x_{26} \prec x_{37}, x_{26} \succ x_{38}, x_{26} \succ x_{39}, \\
& x_{27} \approx x_{28}, x_{27} \approx x_{29}, x_{27} \prec x_{30}, x_{27} \prec x_{31}, x_{27} \prec x_{32}, x_{27} \prec x_{33}, x_{27} \approx x_{34}, x_{27} \prec x_{35}, x_{27} \prec x_{36}, x_{27} \\
& \prec x_{37}, x_{27} \succ x_{38}, x_{27} \succ x_{39} \text {, } \\
& x_{28} \approx x_{29}, x_{28} \prec x_{30}, x_{28} \prec x_{31}, x_{28} \prec x_{32}, x_{28} \approx x_{33}, x_{28} \approx x_{34}, x_{28} \prec x_{35}, x_{28} \approx x_{36}, x_{28} \approx x_{37}, \\
& x_{28} \succ x_{38}, x_{28} \succ x_{39} \text {, } \\
& x_{29} \prec x_{30}, x_{29} \prec x_{31}, x_{29} \prec x_{32}, x_{29} \approx x_{33}, x_{29} \approx x_{34}, x_{29} \prec x_{35}, x_{29} \approx x_{36}, x_{29} \approx x_{37}, x_{29} \succ x_{38}, \\
& x_{29} \succ x_{39} \\
& x_{30} \prec x_{31}, x_{30} \succ x_{32}, x_{30} \succ x_{33}, x_{30} \succ x_{34}, x_{30} \approx x_{35}, x_{30} \succ x_{36}, x_{30} \succ x_{37}, x_{30} \succ x_{38}, x_{30} \succ x_{39} \text {, } \\
& x_{31} \succ x_{32}, x_{31} \succ x_{33}, x_{31} \succ x_{34}, x_{31} \approx x_{35}, x_{31} \succ x_{36}, x_{31} \succ x_{37}, x_{31} \succ x_{38}, x_{31} \succ x_{39} \text {, } \\
& x_{32} \approx x_{33}, x_{32} \approx x_{34}, x_{32} \prec x_{35}, x_{32} \approx x_{36}, x_{32} \approx x_{37}, x_{32} \succ x_{38}, x_{32} \succ x_{39} \text {, } \\
& x_{33} \approx x_{34}, x_{33} \approx x_{35}, x_{33} \prec x_{36}, x_{33} \prec x_{37}, x_{33} \succ x_{38}, x_{33} \succ x_{39}, \\
& \text { - } \quad x_{34} \prec x_{35}, x_{34} \succ x_{36}, x_{34} \succ x_{37}, x_{34} \succ x_{38}, x_{34} \succ x_{39} \text {, } \\
& x_{35} \succ x_{36}, x_{35} \succ x_{37}, x_{35} \succ x_{38}, x_{35} \succ x_{39} \text {, } \\
& \text { - } \quad x_{36} \approx x_{37}, x_{36} \succ x_{38}, x_{36} \succ x_{39} \text {, } \\
& x_{37} \succ x_{38}, x_{37} \succ x_{39} \\
& x_{38} \approx x_{39} \text {. }
\end{aligned}
$$




$$
\begin{gathered}
x_{27} \prec x_{37}, x_{27} \succ x_{38}, x_{27} \succ x_{39}, \\
x_{28} \prec x_{29}, x_{28} \prec x_{30}, x_{28} \prec x_{31}, x_{28} \approx x_{32}, x_{28} \approx x_{33}, x_{28} \approx x_{34}, x_{28} \prec x_{35}, x_{28} \prec x_{36}, x_{28} \prec x_{37}, \\
x_{28} \succ x_{38}, x_{28} \succ x_{39}, \\
x_{29} \prec x_{30}, x_{29} \prec x_{31}, x_{29} \approx x_{32}, x_{29} \approx x_{33}, x_{29} \approx x_{34}, x_{29} \prec x_{35}, x_{29} \prec x_{36}, x_{29} \prec x_{37}, x_{29} \succ x_{38}, \\
x_{29} \succ x_{39}, \\
x_{30} \prec x_{31}, x_{30} \approx x_{32}, x_{30} \succ x_{33}, x_{30} \succ x_{34}, x_{30} \prec x_{35}, \succ x_{36}, x_{30} \succ x_{37}, x_{30} \succ x_{38}, x_{30} \succ x_{39}, \\
x_{31} \prec x_{32}, x_{31} \prec x_{33}, x_{31} \prec x_{34}, x_{31} \prec x_{35}, x_{31} \approx x_{36}, x_{31} \approx x_{37}, x_{31} \succ x_{38}, x_{31} \succ x_{39}, \\
-x_{32} \approx x_{33}, x_{32} \approx x_{34}, x_{32} \prec x_{35}, x_{32} \succ x_{36}, x_{32} \succ x_{37}, x_{32} \succ x_{38}, x_{32} \succ x_{39}, \\
x_{33} \approx x_{34}, x_{33} \prec x_{35}, x_{33} \succ x_{36}, x_{33} \succ x_{37}, x_{33} \succ x_{38}, x_{33} \succ x_{39}, \\
-\quad x_{34} \approx x_{35}, x_{34} \succ x_{36}, x_{34} \succ x_{37}, x_{34} \succ x_{38}, x_{34} \succ x_{39}, \\
x_{35} \succ x_{36}, x_{35} \succ x_{37}, x_{35} \succ x_{38}, x_{35} \succ x_{39}, \\
-\quad x_{36} \succ x_{37}, x_{36} \succ x_{38}, x_{36} \succ x_{39}, \\
-\quad x_{37} \succ x_{38}, x_{37} \succ x_{39}, \\
x_{38} \succ x_{39} .
\end{gathered}
$$

- загроза трапляється часто і регулярно (повторюваність появи загрози) упродовж певного періоду часу, $g_{3}$ :

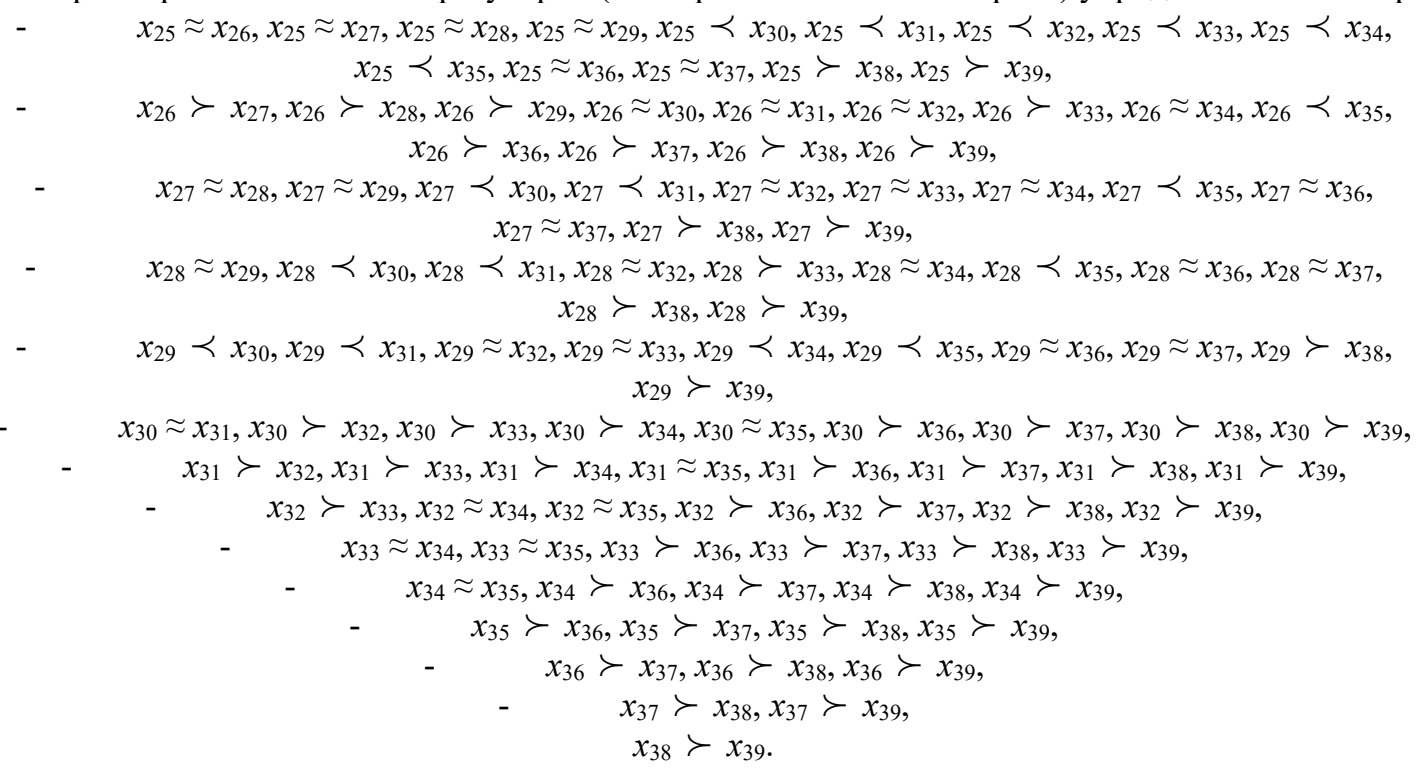

Далі на основі співвідношень (3)-(5) були побудовані матриці відношень $\mu_{g j}\left(x_{i}, x_{j}\right)$ наступним чином: для двох альтернатив, що порівнюються між собою, залежно від їх взаємного впливу матимемо значення відповідного елемента матриці у позиції $\left(x_{i}, x_{j}\right)$. Згідно визначених умов (2) діагональні елементи матриці дорівнюють одиниці. Нижня частина матриці заповнюється оберненими значеннями.

У процесі опрацювання отриманих результатів дані було представлено у вигляді матриць $\mu_{g 1}\left(x_{i}, x_{j}\right)$, $\mu_{g 2}\left(x_{i}, x_{j}\right), \mu_{g 3}\left(x_{i}, x_{j}\right)$, котрі відповідають критеріям $g_{j}$. Самі матриці через обмежений об'єм статті ми в статті опускаємо.

Потім було побудовано згортку відношень $g_{1}, g_{2}, g_{3}$ у вигляді перетину $Q_{1}=g_{1} \cap g_{2} \cap g_{3}$ з функцією належності:

$\mu_{Q 1}\left(x_{i}, x_{j}\right)=\min \left\{\mu_{g 1}\left(x_{i}, x_{j}\right), \mu_{g 2}\left(x_{i}, x_{j}\right), \mu_{g 3}\left(x_{i}, x_{j}\right)\right\}$.

Визначивши відношення строгої переваги за першою згорткою (6), будуємо функцію належності:

$$
\mu_{Q_{1}}^{s}\left(x_{i}, x_{j}\right)=\max \left\{0 ; \mu_{Q_{1}}\left(x_{i}, x_{j}\right)-\mu_{Q_{1}}\left(x_{j}, x_{i}\right)\right\}
$$

Потім визначимо множину недомінованих альтернатив $Q_{l}{ }^{\mu d}$ у множині $\left(X, Q_{l}\right)$ і будуємо функцію належності $\mu_{Q 1}^{\mu \partial}(X)$ :

$$
\mu_{Q 1}^{u \partial}(X)=1-\max \mu_{Q 1}^{s}\left(x_{i}, x_{j}\right) .
$$

Функція належності $\mu_{Q 1}^{\mu \partial}(X)$ має наступний вигляд:

$$
\mu_{Q 1}^{\text {} \partial}(X)=[0 ; 0 ; 0 ; 0 ; 0 ; 1 ; 1 ; 0 ; 0 ; 0 ; 1 ; 0 ; 0 ; 0 ; 0]
$$

Використовуючи згортку критеріїв у вигляді суми $Q_{2}=\sum_{j=1}^{n} \omega_{j} g_{j}$, будуємо нечітке відношення переваги $Q_{2} 3$ функцією належності:

$$
\mu_{Q 2}\left(x_{i}, x_{j}\right)=\sum_{j=1}^{m} \omega_{j} \mu_{g j}\left(x_{i}, x_{j}\right)
$$

Визначаємо відношення строгої переваги за другою згорткою $Q_{2}{ }^{s}$ і будуємо функцію належності:

$$
\mu_{Q 2}^{s}\left(x_{i}, x_{j}\right)=\max \left\{0 ; \mu_{Q 2}\left(x_{i}, x_{j}\right)-\mu_{Q 2}\left(x_{j}, x_{i}\right)\right\}(10)
$$

Визначаємо недоміновані альтернативи за другою згорткою $Q_{2}{ }^{\mu \partial}$ і будуємо функцію належності:

$$
\mu_{Q_{2}}^{\mu d}(X)=1-\max \mu_{Q 2}^{s}\left(x_{j}, x_{i}\right)
$$

Таким чином, нечітка підмножина недомінованих альтернатив стосовно $Q_{2}$ $\mu_{Q_{2}}^{\mu d}(X)=[0 ; 0,112 ; 0 ; 0 ; 0 ; 0,112 ; 0 ; 0 ; 0 ; 0,112 ; 0,690 ; 0 ; 0 ; 0 ; 0 ;]$

Знаходимо спільну множину недомінованих альтернатив за обома згортками $Q^{\mu \partial}(X)=Q_{1}^{\mu \partial}(X) \cap Q_{2}^{\mu \partial}(X)$ з функцією належності:

$$
\mu_{Q^{\mu \nu}}(X)=\min \left\{\mu_{Q_{1}^{\mu \nu}}(X) ; \mu_{Q_{2}^{u \partial}}(X)\right\}
$$

Проведені розрахунки покажуть, що найбільш вагомою альтернативою слід вважати ту, для якої сту- 
пінь недомінованості за обома згортками максималь-

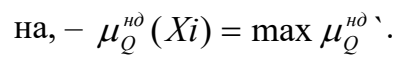

Визначено недоміновану альтернативу за обома згортками:

$\mu_{Q_{2}}^{\mu \partial}(X)=[0 ; 0,112 ; 0 ; 0 ; 0 ; 0,112 ; 0 ; 0 ; 0 ; 0 ; 0,690 ; 0 ; 0 ; 0 ; 0]$

Отримані результати демонструють, що найбільш вагомими загрозами ефективності СУОП аналізованого підприємства $€ x_{30}$ - перевищення частоти травматизму на підприємстві над частотою по галузі та $x_{35}$ грубе порушення правил безпеки праці, допущення аварій.

\section{Висновки}

Фактично отримані результати свідчать про те що на оцінюваному підприємстві відбувся чи може відбутися нещасний випадок.

Перспективи подальших досліджень. Застосування методу багатокритеріального вибору альтернатив на основі нечіткого відношення переваги в процесі оцінювання ефективності системи управління охороною праці підприємства, розглянуте в роботі, дозволяє, на відміну від низки інших методів, більш об'єктивно виокремити недоліки в СУОП, які потенційно можуть призвести до небажаних наслідків i, відповідно, вчасно вжити необхідні заходи для нормалізації ситуації.

\section{References}

DSTU ISO 45001:2019. Systemy upravlinnia okhoronoiu zdorovia ta bezpekoiu pratsi. Vymohy ta nastanovy shchodo zastosuvannia. URL: http://online.budstandart. $\mathrm{com} / \mathrm{ua} /$ catalog/doc-page.html?id_doc $=88004$ (in Ukrainian).

Guidelines on occupational safety and health management systems: ILO-OSH 2001. URL: https:/www.ilo.org/ global/topics/safety-and-health-at-work/normativeinstruments/WCMS_107727/lang--en/index.htm (Last accessed: 22.09.2020).

Hohitashvili H. H., Lapin V. M., Yatsiuk R. A., Storozhuk V. M., \& Melnikov A. V (2016). Osnovy okhorony pratsi. K.: Znannia (in Ukrainian).

Hohitashvili, H. H. (2002). Systemy upravlinnia okhoronoiu pratsi. Lviv : Afisha (in Ukrainian).

Hohitashvili, H. H., Karchevski, Ye. T., \& Lapin, V. M. (2007). Upravlinnia okhoronoiu pratsi ta ryzykom za mizhnarodnymy standartamy. K.: Znannia (in Ukrainian).

Karaim, M. M., Martyniv, V. V., Shtanhret, A. M., Kotlyarevsky, Ya. V., Sukhomlyn, L. Ye., \& Ratushniak, Yu. V. (2016). Antykryzovi tekhnolohii v upravlinni ekonomichnoiu bezpekoiu pidpryiemstva. Lviv: Ukr. akad. drukarstva, 132-142 (in Ukrainian).

Melnikov, A. V. (2018). Stalyi rozvytok informatsiinoi sfery Ukrainy: Napriamy ta perspektyvy. K.: TsUL (in Ukrainian).
Melnikov, A. V., \& Karaim, M. M. (2013). Bahatofaktornyi vybir alternatyvnykh variantiv optymalnoho antykryzovoho rishennia $\mathrm{v}$ protsesi harantuvannia ekonomichnoi bezpeky pidpryiemstva na osnovi nechitkoho vidnoshennia perevahy. Nauk. visn. NLTU Ukrainy, 23(3), 355-362 (in Ukrainian).

Pro okhoronu pratsi: Zakon Ukrainy vid 14.10.1992 № 2694-XII. URL: https://zakon.rada.gov.ua/laws/show/ 2694-12 (in Ukrainian).

Pro Rekomendatsii shchodo pobudovy ta vprovadzhennia systemy upravlinnia okhoronoiu pratsi: Nakaz Derzhavnoho komitetu Ukrainy $\mathrm{z}$ promyslovoi bezpeky, okhorony pratsi ta hirnychoho nahliadu vid 22.02.2008 p. № 35. URL: https://zakon.rada.gov.ua/ rada/show/n0001641-08\#Text (in Ukrainian).

Pro skhvalennia Kontseptsii reformuvannia systemy upravlinnia okhoronoiu pratsi v Ukraini ta zatverdzhennia planu zakhodiv shchodo yii realizatsii: Postanova Kabinetu Ministriv Ukrainy vid 12.12.2018 p. № 989p. URL: https://zakon.rada.gov.ua/laws/show/9892018-\%D1\%80?lang=ru\#Text (in Ukrainian).

Pro zatverdzhennia Polozhennia pro Systemu upravlinnia okhoronoiu pratsi na pidpryiemstvakh elektroenerhetyky: Nakaz Ministerstva enerhetyky ta vuhilnoi promyslovosti Ukrainy vid 09.02.2015 p. № 75. URL: https://zakon.rada.gov.ua/laws/show/z0397-15\#Text (in Ukrainian).

Saaty, T. (1993). Pryniatye reshenyi. Metod analyza yerarkhyi: per. s anhl. M.: Radyo y sviaz (in Russian).

Semeniuk, E. P., Olyanyshen, T. V., Senkivskyi, V. M., Melnikov, A. V., \& Kotlyarevsky, Ya. V. (2012). Ecologization of society: Social role and modelling. Lviv: Ukr. akad. drukarstva, 104.

Storozhuk, V. M. (2015). Otsiniuvannia ta kontrol bezpechnosti promyslovoho pidpryiemstva. Nauk. visn. NLTU Ukrainy, 25(2), 157-161 (in Ukrainian).

Storozhuk, V. M., Dzhyhyrei V. S., \& Sokolovskyi I. A. (2006). Okhorona pratsi ta promyslova ekolohiia $\mathrm{v}$ haluzi: Praktykum z dystsypliny. Lviv: NLTUU (in Ukrainian).

Storozhuk, V. M., Melnikov, A. V., \& Yatsiuk, R. A. (2016). Osoblyvosti protsedury otsiniuvannia stanu bezpechnosti promyslovoho pidpryiemstva. Tekhnol. i tekhn. Drukarstva, 3(53), 35-48. doi: 10.20535/20777264.3(53).2016.89967 (in Ukrainian).

Storozhuk, V. M., Olyanyshen, T. V., Melnikov, A. V., \& Yatsiuk, R. A. (2019). Otsiniuvannia ryzykiv na robochomu mistsi, yak element ryzykooriientovanoho pidkhodu V okhoroni pratsi. Tekhnol. i tekhn. Drukarstva, 1(63), 35-44. doi: 10.20535/20777264.1(63).2019.181997 (in Ukrainian).

Zaichenko, Yu. P. (1991). Yssledovanye operatsyi. Nechetkaia optymyzatsyia. K.: Vyshcha shk. (in Russian).

Zaichenko, Yu. P. (2006). Doslidzhennia operatsii. 7 ed. K.: Slovo (in Ukrainian).

Zhyvko, Z. B. (2013). Metodolohiia upravlinnia ekonomichnoiu bezpekoiu pidpryiemstva. Lviv: LihaPres, 359-374 (in Ukrainian). 